\title{
Disinfection of swine wastewater using chlorine, ultraviolet light and ozone
}

\author{
John J Macauley ${ }^{a}$, Zhimin Qiang ${ }^{b, c, d}$, Craig D. Adams ${ }^{b, c}$, \\ Rao Surampallie, Melanie R. Mormile ${ }^{a, c, *}$

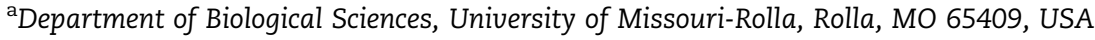 \\ ${ }^{b}$ Department of Civil, Architectural and Environmental Engineering, University of Missouri-Rolla, MO 65409, USA \\ ${ }^{c}$ Environmental Research Center for Emerging Contaminants, University of Missouri-Rolla, Rolla, MO 65409, USA \\ ${ }^{\mathrm{d}}$ State Key Laboratory of Environmental Aquatic Chemistry, Research Center for Eco-Environmental Sciences, \\ Chinese Academy of Sciences, Beijing 100085, China \\ eU.S. Environmental Protection Agency, Region 7, Kansas City, KS 66101, USA
}

\section{A R T I C L E I N F O}

Article history:

Received 20 July 2005

Received in revised form

18 March 2006

Accepted 26 March 2006

Keywords:

Disinfection

Antibiotic resistance

Swine wastewater

Chlorine

Ultraviolet light

Ozone

\begin{abstract}
A B S T R A C T
Veterinary antibiotics are widely used at concentrated animal feeding operations (CAFOs) to prevent disease and promote growth of livestock. However, the majority of antibiotics are excreted from animals in urine, feces, and manure. Consequently, the lagoons used to store these wastes can act as reservoirs of antibiotics and antibiotic-resistant bacteria. There is currently no regulation or control of these systems to prevent the spread of these bacteria and their genes for antibiotic resistance into other environments. This study was conducted to determine the disinfection potential of chlorine, ultraviolet light and ozone against swine lagoon bacteria. Results indicate that a chlorine dose of $30 \mathrm{mg} / \mathrm{L}$ could achieve a 2.2-3.4 log bacteria reduction in lagoon samples. However, increasing the dose of chlorine did not significantly enhance the disinfection activity due to the presence of chlorine-resistant bacteria. The chlorine resistant bacteria were identified to be closely related to Bacillus subtilis and Bacillus licheniformis. A significant percentage of lagoon bacteria were not susceptible to the four selected antibiotics: chlortetracycline, lincomycin, sulfamethazine and tetracycline (TET). However, the presence of both chlorine and TET could inactivate all bacteria in one lagoon sample. The disinfection potential of UV irradiation and ozone was also examined. Ultraviolet light was an effective bacterial disinfectant, but was unlikely to be economically viable due to its high energy requirements. At an ozone dose of $100 \mathrm{mg} / \mathrm{L}$, the bacteria inactivation efficiency could reach $3.3-3.9 \mathrm{log}$
\end{abstract}

(c) 2006 Elsevier Ltd. All rights reserved.

\section{Introduction}

The number and size of concentrated animal feeding operations (CAFOs) are on the rise, and with them comes a rise in the amount of waste produced. In the United States, there are approximately 1.3 million livestock farms, with about 257,000 of these farms regarded as animal feeding operations (AFOs) (US EPA, 2003). Animal agriculture commonly uses anaerobic lagoons and pit systems for waste disposal (Sweeten, 1980). These lagoons depend on both microbial activity and

\footnotetext{
*Corresponding author. Department of Biological Sciences, University of Missouri-Rolla, 105 Schrenk Hall, Rolla, MO 65409-1120, USA. Tel.: +1573 3416346; fax: +15733414821.

E-mail address: mmormile@umr.edu (M.R. Mormile).
}

0043-1354/\$ - see front matter ๔ 2006 Elsevier Ltd. All rights reserved.

doi:10.1016/j.watres.2006.03.021 
management practices such as solids separation prior to treatment, periodic solids removal, and suitable organic loadings to help maintain functionality (Barker and Drigger, 1985; Miner et al., 2000). Factors that can adversely affect microbial activity include organic overloading, temperature and $\mathrm{pH}$ fluctuations, salt buildup, ammonia accumulation, and the use of disinfectants and antibiotics (Hilpert et al., 1984; Poels et al., 1984; Hansen et al., 1998; Zahn et al., 2001; Do et al., 2003).

Veterinary antibiotics are widely used as additives in food or water at CAFOs to prevent and treat animal disease outbreaks due to their prophylactic and therapeutic qualities as well as to promote animal growth (Carlson and Fangman, 2000). It is estimated that more than 3000 tons of veterinary antibiotics are used in the European Union, and from 8500 to 11,200 tons in the United States each year (Dell, 2003). However, these antibiotics pass through animal bodies and are commonly excreted in urine, feces and manure as parent compounds, conjugates, or oxidation and hydrolysis byproducts (Tolls, 2001). The animal wastes are discharged to anaerobic lagoons for biological treatment and temporary storage. However, many antibiotics are not amenable to biodegradation (Daughton and Ternes, 1999) and accumulate in the lagoons. As a result, the lagoons can act as reservoirs of various antibiotics and subsequently, a portion of lagoon bacteria may develop strong resistance to these antibiotics. Seepage and runoff of the lagoon wastewater and farm application of the lagoon sediments as fertilizer may lead to the contamination of both surface and groundwater with antibiotics and antibiotic-resistant bacteria, thus posing a severe threat to public health (Chee-Sanford et al., 2001). In fact, a variety of antibiotics were detected at relevant concentrations in U.S. streams in a recent national reconnaissance (Kolpin et al., 2002). Goni-Urriza et al. (2000) evaluated the impact of an urban effluent on antibiotic resistance of freshwater bacterial populations and reported that $72 \%$ of Aeromonas strains and $20 \%$ of Enterobacteriaceae strains were resistant to nalidixic acid. Enterobacteriaceae also exhibited resistance to tetracycline (TET) (24\%) and beta-lactams (21\%), and Aeromonas to TET (28\%) and cotrimoxazole (27\%). Recent studies have also shown that the potential contamination of groundwater with bacteria and antibiotic-resistant genes was found up to $100 \mathrm{~m}$ downstream of swine lagoons (Chee-Sanford et al., 2001; Krapac et al., 1998, 2000).

There has been little research on disinfection of the bacteria associated with animal wastes generated at CAFOs. Chlorine, UV light and ozone are commonly used as disinfectants in water and wastewater treatment facilities. The major objective of this study was to examine the potential disinfection efficiency of chlorine, UV light and ozone on swine lagoon bacteria. The susceptibility of lagoon bacteria to selected antibiotics, including chlortetracycline (CTC), lincomycin (LIN), sulfamethazine (SMN) and TET, was also tested. It was reported that microorganisms associated with cell debris, fecal material, or wastewater solids were more protected from disinfection (Berman et al., 1988). Therefore, the effect of suspended solids on disinfection efficiency was assessed in this work.

\section{Materials and methods}

\subsection{Lagoon samples}

Wastewater samples were obtained from lagoons at two different swine production facilities located in central Missouri. One is classified as a functional lagoon while the other is classified as non-functional. The functional lagoon (Lagoon A) is a recharge pit system with semiannual solids removal. The lagoon receives swine wastes from two barns that can hold 2000 weaner pigs and are collected in a pit before being flushed and washed down. The water recycled from the lagoon is used to wash down the wastes from the pit. The lagoon size is $65.5 \mathrm{~m}(\mathrm{~L}) \times 58.8 \mathrm{~m}(\mathrm{~W})$ with the depth ranging from 2.4 to $5.5 \mathrm{~m}$. The aqueous phase of this lagoon turns purple in the warm weather. The purple color indicates the probable presence of photosynthetic purple bacteria that can consume odoriferous compounds such as hydrogen sulfide, ammonia, and excess volatile fatty acids (Kobayashi et al., 1983; Do et al., 2003). The non-functional study lagoon (Lagoon B) is the initial stage of a two-stage system without solid separation, recycle and solid removal. The first-stage lagoon receives wastes from three barns that contain approximately 375 hogs ranging in age from farrowing with sows to finishing. This farm uses groundwater to flush the swine wastes into this lagoon. This first stage is a primary treatment lagoon for the swine wastes where solids accumulate, while the second stage receives overflow from the initial stage lagoon. The treatment lagoon size is $54 \mathrm{~m}$ $(\mathrm{L}) \times 21.6-36.6 \mathrm{~m}$ (W) with the depth ranging from 0.3 to $2.7 \mathrm{~m}$. The sludge depth varies from 0.3 to $1.2 \mathrm{~m}$. This lagoon has a grayish or black color and possesses a high sludge accumulation. The black color is indicative of organic overloading in the lagoon (USDA, Natural Resources Conservation Service, 1999).

Samples were taken at a depth of $0.3 \mathrm{~m}$ below the surface at the middle of each lagoon by using a Van Dorn style water sampler (Cole Parmer, Vernon Hills, IL). After being dispensed into sterile Nalgene ${ }^{\circledR}$ polyethylene bottles $(1 \mathrm{~L})$, the samples were immediately stored on ice, transported to the lab, and maintained at $4{ }^{\circ} \mathrm{C}$ until used for experiments.

To assess the effect of suspended solids on the disinfection potential, a portion of lagoon samples was centrifuged at $1000 \mathrm{~g}$ for $5 \mathrm{~min}$ at $4^{\circ} \mathrm{C}$ by using an IEC B-22M Programmable centrifuge (International Equipment Company, Needham Heights, MA). The supernatant was thereafter stored on ice until use to suppress bacterial growth. A low speed and a short time for centrifugation were adopted here in an attempt to only remove large suspended particles but retain most of the bacteria in the supernatant.

Both centrifuged and non-centrifuged samples were buffered with $10 \mathrm{mM} \mathrm{KH}_{2} \mathrm{PO}_{4}$, and adjusted to $\mathrm{pH} 7.7$ for experiments. This $\mathrm{pH}$ value was selected because it closely represented the natural $\mathrm{pH}$ conditions of both study lagoons. The $\mathrm{pH}$ values of Lagoons A and B were measured to be 7.85 and 7.42, respectively (Table 1). The typical physical-chemical properties of the centrifuged samples from Lagoons $A$ and $B$ are described in Table 1. 
Table 1 - Typical physical-chemical properties of centrifuged lagoon samples

\begin{tabular}{|c|c|c|}
\hline Properties & Lagoon A & Lagoon B \\
\hline $\mathrm{pH}$ & 7.85 & 7.42 \\
\hline $\mathrm{DOC}(\mathrm{mg} / \mathrm{L})$ & 425.2 & 222.7 \\
\hline $\mathrm{SCOD}(\mathrm{mg} / \mathrm{L})$ & 1215 & 839 \\
\hline $\mathrm{NH}_{3}-\mathrm{N}(\mathrm{mg} / \mathrm{L})$ & 420 & 279 \\
\hline Total alkalinity $(\mathrm{m} / \mathrm{L})$ & 1853 & 1235 \\
\hline Conductivity $(\mu \mathrm{S} / \mathrm{cm})$ & 5070 & 3300 \\
\hline TDS (mg/L) & 3380 & 2200 \\
\hline Acetate (mg/L) & 441.6 & 278.8 \\
\hline Chloride (mg/L) & 215.2 & 95.8 \\
\hline Bromide (mg/L) & 4.4 & 2.5 \\
\hline Phosphate (mg/L) & 61.1 & 46.4 \\
\hline Sulfate (mg/L) & 4.1 & 68.5 \\
\hline $\mathrm{UVA}_{254 \mathrm{~nm}}\left(\mathrm{~cm}^{-1}\right)$ & 2.98 & 1.66 \\
\hline $\mathrm{UVT}_{254 \mathrm{~nm}}(\% @ 1 \mathrm{~cm})$ & 0.10 & 2.19 \\
\hline SUVA (L/mg-m) & 0.70 & 0.75 \\
\hline
\end{tabular}

\subsection{Reagents}

Potassium phosphate monobasic (HPLC grade, 99.6\%), certified ACS grade hydrochloric acid (37.6\%) and sodium hydroxide $(98.5 \%)$ were purchased from Fisher Scientific (Fairlawn, $\mathrm{NJ}$ ). $\mathrm{NaOH}$ and $\mathrm{HCl}$ solutions were prepared in a series of appropriate concentrations and sterilized for $\mathrm{pH}$ adjustment. Sodium hypochlorite ( $>4 \%$ by weight), obtained from Aldrich (Milwaukee, WI), was used as the source of free chlorine. Its real concentration was determined to be $44,400 \mathrm{mg} / \mathrm{L}$ as $\mathrm{Cl}_{2}$. CTC, SMN and TET were purchased from Sigma (St. Louis, $\mathrm{MO})$, and LIN was purchased from ICN Biomedicals Inc. (Aurora, OH). Millipore water with a resistivity of $>18.2 \mathrm{M} \Omega \mathrm{cm}$ was produced by a Millipore Simplicity 185 water purification system (Millipore Co., Bedford, MA) from distilled water.

\subsection{Analysis}

Sample $\mathrm{pH}$ was measured with a digital Corning $\mathrm{pH}$ meter (Model 320) coupled with a combination pH probe (Corning Inc., Corning, NY). Dissolved organic carbon (DOC) was analyzed by using a Total Organic Carbon Analyzer (Model TOC-5000A, Shimadzu Co., Kyoto, Japan) after appropriate sample dilution. Soluble chemical oxidation demand (SCOD), free ammonia, total alkalinity were determined by Hach methods 8000 (dichromate reactor digestion), 10045 (AccuVac Ampuls), and 8203 (digital titration with $\mathrm{H}_{2} \mathrm{SO}_{4}$ solution) with a DR/2010 portable spectrophotometer (Hach Co., Loveland, CO). A digital conductivity meter coupled with a platinum probe from Fisher Scientific (Fairlawn, NJ) was used to measure sample conductivity and total dissolved solids (TDS) concentration. The concentrations of acetate, chloride, bromide, phosphate and sulfate were determined by using ion chromatography (Model DX-120, Dionex Co., Sunnyvale, CA) with a Dionex IonPac AS9-HC column $(4 \times 250 \mathrm{~mm})$ for ion separation and $9 \mathrm{mM} \mathrm{Na} \mathrm{Na}_{2} \mathrm{CO}_{3}$ solution as mobile phase running isocratically at a flow rate of $1.0 \mathrm{~mL} / \mathrm{min}$. A Varian spectrophotometer (Model Cary 50 Conc., Varian Australia PTY Ltd., Australia) was used to determine the ultraviolet absorbance of lagoon wastewater at $254 \mathrm{~nm}$ and the concentration of aqueous ozone at $260 \mathrm{~nm}$. Free chlorine and total chlorine concentrations were analyzed by using Hach DPD methods 8021 and 8167, respectively, after appropriate sample dilution.

\subsection{Disinfection procedures}

In the chlorination experiments, sodium hypochlorite was used as the source of free chlorine. Five-milliliter aliquots of sample were distributed to a series of $25-\mathrm{mL}$ sterile conical vials. A desired amount of chlorine was spiked into these vials to achieve chlorine doses of $5,10,30,50,100,250$, and $500 \mathrm{mg} /$ L. After addition of chlorine, the samples were immediately vortexed and allowed to react for $2.5 \mathrm{~h}$ before performing enumeration tests. The disinfection reactions proceeded on ice (about $3-4{ }^{\circ} \mathrm{C}$ ) to simulate unfavorable winter temperature conditions. In warm seasons, higher disinfection efficiencies are anticipated because disinfection reactions will proceed more quickly. Sodium hypochlorite was added to a new sample every $15 \mathrm{~min}$. This time interval was required to complete plating of each sample in the subsequent bacterial enumeration tests.

For the chlorination tests and subsequent antibiotic exposures, the samples from each lagoon were first centrifuged, and a desired amount of chlorine was added thereafter with a dose of 0,50 and $500 \mathrm{mg} / \mathrm{L}$. After the disinfection was allowed to proceed for $2.5 \mathrm{~h}$ on ice, the samples were plated onto brain heart infusion (BHI) medium amended with individual antibiotics. The concentration of LIN, CTC and TET in the BHI medium was prepared at $32 \mathrm{mg} / \mathrm{L}$, while a high concentration of $256 \mathrm{mg} / \mathrm{L}$ was used for SMN due to its lower antibiotic effectiveness (Salmon et al., 1995).

During the ultraviolet light experiments, a $200-\mathrm{mL}$ graduated glass cylinder (I.D. $3.7 \mathrm{~cm}$ ) was used as the reactor with aluminum foil wrapped around the outside to enhance radiation efficiency. A low-pressure mercury vapor $254 \mathrm{~nm}$ lamp (Pen Ray, Model 90-0004-01) was situated along the central line of the reactor. The light intensity of the lamp at $254 \mathrm{~nm}$ was $5.4 \mathrm{~mW} / \mathrm{cm}^{2}$ at $1.9-\mathrm{cm}$ radius as provided the manufacturer (UVP Inc., Upland, CA). The effective dose rates of the UV lamp were calculated to be 0.366 and $1.282 \mathrm{~mW} / \mathrm{cm}^{2}$ for Lagoon A and Lagoon B samples, respectively, based on the wastewater absorbance and reactor geometry using the Point Source Summation Method (White, 1992). This apparatus was allowed to warm up for $10 \mathrm{~min}$ before initiating the experiments. The lagoon sample $(180 \mathrm{~mL})$ was added into the reactor and mixed gently with a magnetic stir bar. An aliquot, $5 \mathrm{~mL}$, was periodically withdrawn midway down the reactor through a Teflon tube and glass syringe at pre-selected times to perform bacteria enumeration tests.

For the ozonation experiments, gaseous ozone was produced from compressed oxygen by corona discharge in an ozone generator (Model GLS-1, PCI-WEDECO Environmental Technologies, West Caldwell, NJ). An ozone gas stream was bubbled through a stone diffuser into an ozone receiving solution (Millipore water buffered with $10 \mathrm{mM} \mathrm{KH}_{2} \mathrm{PO}_{4}$ and $\mathrm{pH}$ adjusted to 7.7). Ozone was saturated in the aqueous phase 
within $5 \mathrm{~min}$. The ozone-saturated solution was spiked into a series of $25-\mathrm{mL}$ sterile conical vials, each containing $5 \mathrm{~mL}$ of lagoon sample, to reach an ozone dose of 10, 20, 40, 100, 150, and $200 \mathrm{mg} / \mathrm{L}$. Other procedures were exactly the same as those used in the chlorination experiments. Ozone residual was not monitored during the reaction because ozone decay was expected to be fast in the lagoon wastewaters. Preliminary experiments indicated that the half-life of ozone decay was about $3 \mathrm{~min}$ in $\mathrm{pH} 7.0$ Millipore water buffered with $10 \mathrm{mM} \mathrm{KH}_{2} \mathrm{PO}_{4}$. The lagoon wastewaters contained a significant amount of organic materials; thus, all the ozone would be depleted within the $2.5 \mathrm{~h}$ reaction time. The effect of sample dilution due to batch addition of the ozone-saturated solution was corrected for during bacteria enumeration.

All the chlorination, UV irradiation, and ozonation of lagoon bacteria were conducted in two parallel experiments (i.e., sample duplicates) for statistical data analysis.

\subsection{Bacteria enumeration}

Both standard most probable number (MPN) analysis and plate count technique were used for enumerating bacteria. BHI medium (37 g/L; Beckton-Dickinson) was used for both analyses.

MPN analysis was performed by preparing 10-fold serial dilutions of the disinfectant-treated sample to $10^{-10}$ in triplicate. The serially diluted tubes were incubated at $37^{\circ} \mathrm{C}$ for 3 days before analyzing. Tubes exhibiting increased turbidity after incubation were considered as positive. Final enumeration of bacteria was done by comparing the distribution pattern of positive tubes with a standard MPN table (Atlas et al., 1984).

The plate count analysis was performed first by a single 10fold serial dilution of the disinfectant-treated sample to $10^{-10}$. Next, approximately 20-25 sterile glass beads of 3-mm diameter were dispensed to the BHI medium plates. An aliquot of $100 \mu \mathrm{L}$ of sample was withdrawn from each dilution tube and plated onto the center of three plates (in triplicate). The plates were shaken in a side-to-side motion for approximately $10 \mathrm{~s}$ to evenly distribute the sample. After removing the glass beads, the plates were incubated in an inverted position at $37^{\circ} \mathrm{C}$ for 3 days before analyzing. After incubation, the plate colonies were counted by using a Darkfield Colony Counter (Reichert Scientific Instruments, Buffalo, NY).

\subsection{DNA extraction and sequencing}

DNA was extracted from cultures grown overnight by using the UltraClean Soil DNA Kit (MO BIO Laboratories, Inc., Solana Beach, CA). The 16S rDNA of bacteria resistant to high levels of chlorine was amplified by using the universal bacterial primers $27 \mathrm{~F}$ and 1492R synthesized by MWG Biotech (High Point, NC). The sequences of the $27 \mathrm{~F}$ and $1492 \mathrm{R}$ primers are $5^{\prime}$ AGA GTT TGA TC(AC) TGG CTC A-3' and 5'-TAC GG(CT) TAC CTT GTT ACG ACT T-3', respectively. The PCR mixture $(20 \mu \mathrm{L})$ consisted of $30 \mathrm{pmol}$ of each primer, $1 \mathrm{U}$ Taq DNA polymerase, $2 \mu \mathrm{L} 10 \times$ PCR buffer, $1 \mu \mathrm{L} 25 \mathrm{mM} \mathrm{Mg}(\mathrm{OAC})_{2}, 0.2 \mu \mathrm{L} 200 \mathrm{uM}$ $\mathrm{dNTP}$, and $1 \mu \mathrm{L}$ of the DNA extraction from each isolate. A touchdown PCR program was used to amplify the target of interest. Amplification products were confirmed by running
$10 \mu \mathrm{L}$ of aliquots of each PCR reaction on a $0.7 \%$ agarose gel stained with ethidium bromide. Restriction fragment length profiles (RFLPs) were conducted as a fast screen of chlorineresistant isolates to determine differences in these bacteria by nucleotide sequence. Briefly, colonies from the highest chlorine dosed (i.e., $500 \mathrm{mg} / \mathrm{L} \mathrm{Cl}_{2}$ ) samples were isolated. DNA was extracted and purified as detailed above. A general RFLP double digest was performed: $7 \mu \mathrm{L}$ water, $2 \mu \mathrm{L}$ buffer $\mathrm{C}$ (final assay concentrations - $50 \mathrm{mM}$ Tris- $\mathrm{HCl}, \mathrm{pH} 8.0,10 \mathrm{mM} \mathrm{MgCl}_{2}$, and $50 \mathrm{mM} \mathrm{NaCl}$ ), $1 \mu \mathrm{L}$ bovine serum albumin, $0.5 \mu \mathrm{L}$ enzyme Rsa I, $0.5 \mu \mathrm{L}$ enzyme Hae III, and $10.5 \mu \mathrm{L}$ PCR product. Reaction mixtures were incubated at $37^{\circ} \mathrm{C}$ for $3 \mathrm{~h}$. All RFLP reactions were analyzed with electrophoresis by using an ethidium bromide stained $2.0 \%$ agarose gel.

Amplicons of the 16S rDNA were purified by using the QIAGEN QIAquick PCR Purification Kit, and subsequently sent to MWG Biotech for Comfort Read ${ }^{\circledR}$ sequencing reactions and analysis. The 16S rDNA sequences of the above isolates were edited and BLAST searched in GenBank by using CHROMAS PRO to determine the closest potential relative.

\section{Results}

\subsection{Disinfection with chlorine}

The effect of chlorine dose on bacteria inactivation is shown in Fig. 1. Results indicate that for all lagoon samples, the bacteria were effectively inactivated as the chlorine dose was increased from 0 to $30 \mathrm{mg} / \mathrm{L}$. However, the inactivation curve leveled off as the chlorine dose was further increased from 50 to $500 \mathrm{mg} / \mathrm{L}$. For example, the disinfection efficiency was 3.1 log for Lagoon A non-centrifuged sample at the chlorine dose of $30 \mathrm{mg} / \mathrm{L}$. At the chlorine dose of $500 \mathrm{mg} / \mathrm{L}$, the disinfection efficiency only increased to $3.6 \mathrm{log}$. A complete inactivation of bacteria could not be achieved even at a chlorine concentration as high as $500 \mathrm{mg} / \mathrm{L}$. This implies that a small portion of bacteria was highly resistant to chlorine disinfection in both non-centrifuged (raw) and centrifuged lagoon samples.

Results in Fig. 1 also show that a higher efficiency of bacteria inactivation was achieved in Lagoon A than in Lagoon $\mathrm{B}$. This may be due to the difference in the starting bacteria populations and the microbial diversity as well. For example, at the chlorine dose of $30 \mathrm{mg} / \mathrm{L}$, the disinfection efficiency was $2.2 \mathrm{log}$ for the non-centrifuged sample of Lagoon B as compared to $3.1 \log$ for that of Lagoon A. For the same lagoon, bacteria inactivation was slightly more effective in the centrifuged sample than in the raw sample. This indicates that the suspended solids did inhibit bacteria inactivation, but the inhibition was not significant.

The decay of total chlorine was monitored as the disinfection proceeded for the chlorine doses of 5, 30, and $500 \mathrm{mg} / \mathrm{L}$, as shown in Fig. 2. Results indicate that for the same lagoon, the raw sample consumed total chlorine more rapidly than the centrifuged sample, as affected by the different amounts of suspended solids present. Furthermore, less residual total chlorine was detected in the samples of Lagoon A than those in Lagoon $\mathrm{B}$. This probably resulted in more bacteria removal in Lagoon A samples as observed in our experiments. At the 


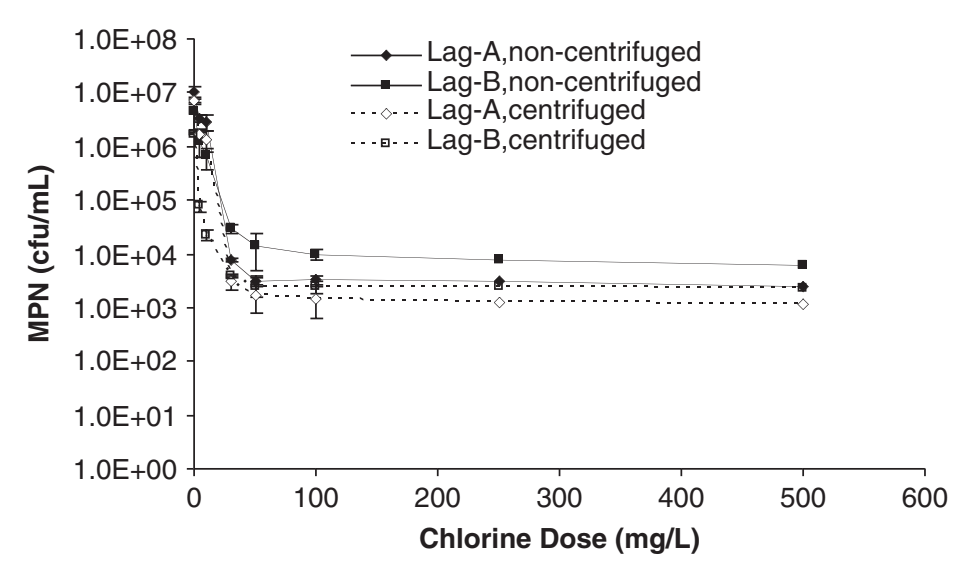

Fig. 1 - Effect of chlorine dose on bacteria inactivation. Data are from 3-tube MPN assays that were run twice (mean of $\mathrm{MPN} \pm$ standard deviation). Experimental conditions: $10 \mathrm{mM} \mathrm{KH}_{2} \mathrm{PO}_{4}, \mathrm{pH} 7.7,2.5 \mathrm{~h}$ disinfection time (on ice).
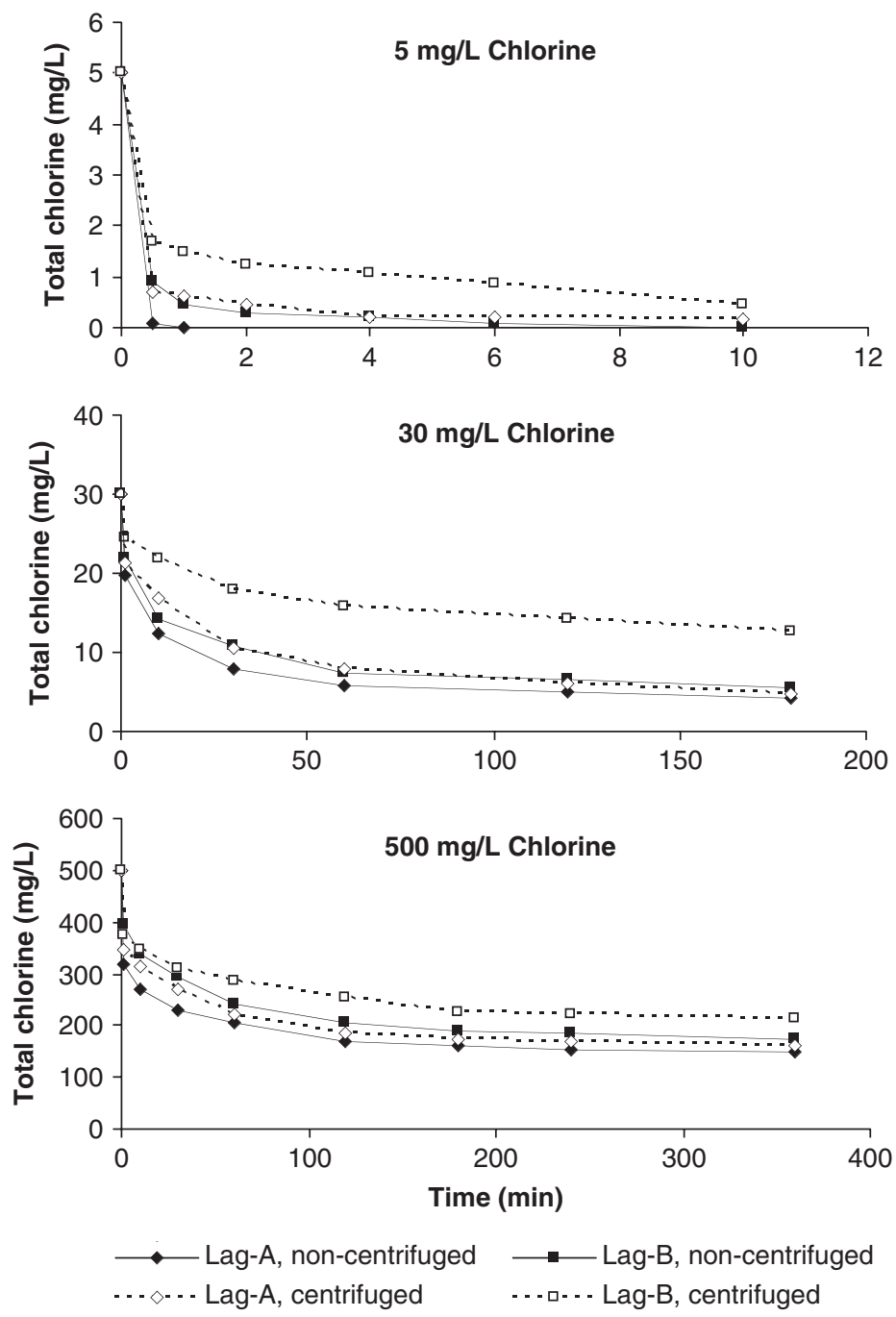

Fig. 2 - Decay of total chlorine as a function of disinfection time. Experimental conditions: $10 \mathrm{mM} \mathrm{KH}_{2} \mathrm{PO}_{4}$, $\mathrm{pH} 7.7$, on ice.

chlorine dose of $5 \mathrm{mg} / \mathrm{L}$, almost all total chlorine was consumed after $10 \mathrm{~min}$. At the chlorine dose of $30 \mathrm{mg} / \mathrm{L}$, the concentration of residual total chlorine was $12.6 \mathrm{mg} / \mathrm{L}$ for the centrifuged Lagoon B sample, and ranged from 4.2 to $5.4 \mathrm{mg} / \mathrm{L}$ for the other three samples after $3 \mathrm{~h}$. When the chlorine dose increased to $500 \mathrm{mg} / \mathrm{L}$, a significant amount of residual total chlorine (150-215 mg/L) was detected in all samples even after $6 \mathrm{~h}$. Although the residual total chlorine persisted throughout the course of disinfection at a significantly high concentration, approximately $1000-5000 \mathrm{cfu} / \mathrm{mL}$ bacteria survived the 
disinfection process, exhibiting a high resistance to chlorine disinfection.

It should be pointed out that the breakpoint of chlorination had never been reached even at the highest chlorine dose of $500 \mathrm{mg} / \mathrm{L}$. A $\mathrm{Cl}_{2}: \mathrm{N}$ ratio of $7.6: 1$ is required to reach the breakpoint of chlorination where the residual combined chlorine level is reduced to a minimum. After the breakpoint, free chlorine starts to predominate instead of combined chlorines. The typical ammonia concentrations were determined to be 420 and $279 \mathrm{mg} / \mathrm{L}$ (as $\mathrm{NH}_{3}-\mathrm{N}$ ) in the samples of Lagoons A and B, respectively (Table 1 ). To reach the breakpoint, a chlorine dose of 3192 and $2120 \mathrm{mg} / \mathrm{L}$ would be required for the samples of Lagoons $A$ and $B$, respectively. The second-order rate constant of monochloramine formation reaction was reported to be as high as $3.07 \times 10^{6}\left(\mathrm{M}^{-1} \mathrm{~s}^{-1}\right)$ at $25^{\circ} \mathrm{C}$ (Qiang and Adams, 2004). Therefore, upon the addition of chlorine, ammonia would rapidly consume the majority of chlorine to primarily form monochloramine. A small portion of chlorine may also be directly consumed by bacteria and dissolved natural organic materials present in the lagoon samples, depending on respective reaction rate constants. As a result, the total chlorine monitored mainly consisted of monochloramine, while the concentration of free chlorine was negligible. The primary disinfectant was actually monochloramine, instead of free chlorine, during the course of bacteria inactivation.

\subsection{Chlorine-resistant isolates}

As stated above, the disinfection curves (Fig. 1) leveled off in the chlorine dose range of $50-500 \mathrm{mg} / \mathrm{L}$ for all lagoon samples, suggesting the presence of chlorine-resistant bacteria. These chlorine-resistant bacteria were isolated and identified. Results indicate that two unique colony-types dominated the culture plates at a chlorine dose of $30 \mathrm{mg} / \mathrm{L}$. Above this chlorine dose, only two colony-types were observed to survive the chlorine disinfection in each lagoon sample. Five colonies, possessing either unique morphology, from each lagoon were isolated and restriction fragment length profiling (RFLP) double digests were performed on each. The RFLP double digests yielded exactly the same patterns for all isolates. However, these colonies were distinguishable by their morphologies. The first isolate, denoted C1, formed colonies approximately $7 \mathrm{~mm}$ in diameter with volcanic morphology in appearance. The second isolate, denoted C2, formed colonies approximately $25 \mathrm{~mm}$ in diameter, were irregular and with globular lobes. A candidate of each isolate was selected for sequencing analysis of their $16 \mathrm{~S}$ rDNA. The BLAST results indicate that the two isolates, $\mathrm{C} 1$ and $\mathrm{C} 2$, were most closely related to Bacillus subtilis and Bacillus licheniformis, respectively, both with $99 \%$ similarity to their prospective relatives. Our confirming experiments show that the two isolates demonstrated their ability to grow overnight on BHI media amended with an initial concentration of $500 \mathrm{mg} / \mathrm{L}$ chlorine. Although it was observed that total chlorine continuously decayed due to the reaction between chlorine and the BHI medium (e.g., $180 \mathrm{mg} / \mathrm{L}$ after $1 \mathrm{~min}, 90 \mathrm{mg} / \mathrm{L}$ after $1 \mathrm{~h}$, and $10 \mathrm{mg} / \mathrm{L}$ after $15 \mathrm{~h}$ ), it clearly indicated on a qualitative basis that the isolates were resistant to chlorine.

\subsection{Effect of chlorine on antibiotic-resistant bacteria}

In the swine facility where Lagoon B was located, only bacitracin was applied for the treatment of swine disease. In contrast, in the swine facility where Lagoon A was located, a large number of antibiotics were applied to swine including amikacin, amoxicillin, ampicillin, cephalexin, chlortetracycline, LIN, oxytetracycline, procaine penicillin, sulfadimethoxine, sulfamethoxazole, tiamulin, tilmicosin, and trimethoprim. Our analysis of lagoon samples with LC/MS indicated that no antibiotics were detected in Lagoon $\mathrm{B}$. However, four antibiotics were detected in Lagoon A: LIN $(1.47 \mathrm{mg} / \mathrm{L})$, oxytetracycline $(0.11 \mathrm{mg} / \mathrm{L})$, isochlorotetracycline (a major degradation product of CTC, $0.4 \mathrm{mg} / \mathrm{L}$ ), and SMN (1.24 mg/L).

Based on the above information, LIN, CTC, SMN and TET were selected as model antibiotics in this study. The effect of chlorine on antibiotic-resistant bacteria is shown in Fig. 3. Results indicate that without chlorine treatment (i.e., $0 \mathrm{mg} / \mathrm{L}$ chlorine dose), a significant portion of bacteria could survive antibiotic-amended BHI medium. The percentages of culturable bacteria, as compared to antibiotic-free controls, were $83 \%, 46 \%, 79 \%$ and $22 \%$ in Lagoon A samples, and 23\%, $100 \%$, $29 \%$ and $4 \%$ in Lagoon B samples, corresponding to CTC-, LIN, SMN- and TET-amended media, respectively. This clearly shows that the lagoon bacteria have reduced susceptibility to selected antibiotics. When bacteria were challenged with both chlorine, at 50 and $500 \mathrm{mg} / \mathrm{L}$, and antibiotics, a statistically notable significance of bacteria inactivation was only observed for TET-amended cultures from Lagoon A, and LINand TET-amended cultures from Lagoon B, as compared to respective antibiotic-free control cultures. The TET-resistant bacteria in Lagoon $B$ were completely inactivated with exposure to 50 or $500 \mathrm{mg} / \mathrm{L}$ chlorine. In general, the bacteria from Lagoon A exhibited a weaker susceptibility to antibiotics than those from Lagoon B. This is consistent with the historical use of many antibiotics including the ones analyzed in the swine facility associated with Lagoon A. As mentioned above, four antibiotics were detected in Lagoon A with a concentration ranging from 0.11 to $1.47 \mathrm{mg} / \mathrm{L}$. The presence of these antibiotics may provide a selection pressure on the bacteria of Lagoon A to develop and maintain antibiotic resistance. However, TET resistance did not confer a protection against chlorine inactivation. It appears that bacteria that were exposed to TET were more susceptible to chlorine. One mechanism of chlorine damage is the disruption of cell membranes (Venkobachar et al., 1997). On the other hand, one of the mechanisms of TET resistance is the production of efflux membrane pumps that transport protons into the cell while pumping TET out (Walsh, 2003). These efflux pumps might allow more free chlorine to interact with bacterial cell membranes and lead to their disruption.

\subsection{Disinfection with UV light}

The effect of UV dose on bacteria inactivation is shown in Fig. 4. Results indicate that UV is effective in disinfecting all lagoon samples, although a slightly higher efficiency was observed for the centrifuged samples. At the irradiation time 


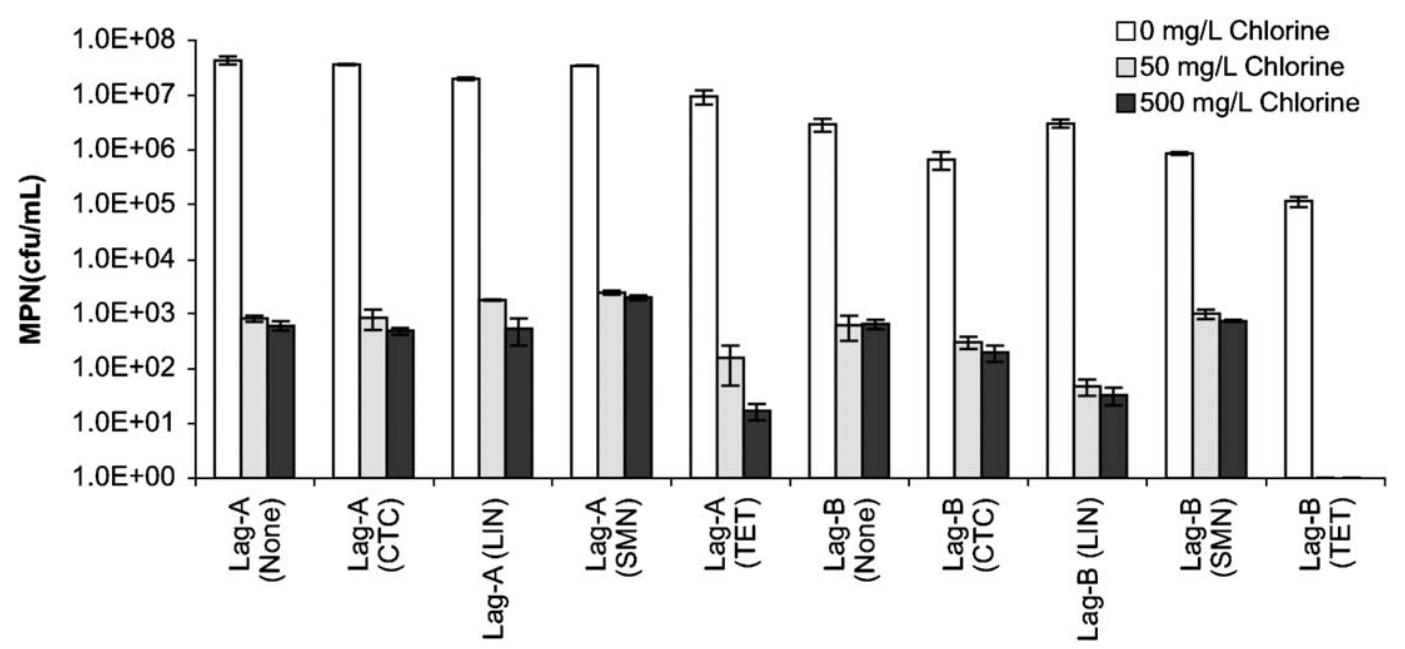

Fig. 3 - Effect of chlorine dose on antibiotic-resistant bacteria inactivation. Data are from 3-plate count assays that were run twice (mean \pm standard deviation). Experimental conditions: $10 \mathrm{mM} \mathrm{KH}_{2} \mathrm{PO}_{4}, \mathrm{pH} 7.7,2.5 \mathrm{~h}$ chlorination time (on ice); $32 \mathrm{mg} / \mathrm{L}$ CTC, LIN and TET, and $256 \mathrm{mg} / \mathrm{L}$ SMN in BHI media.

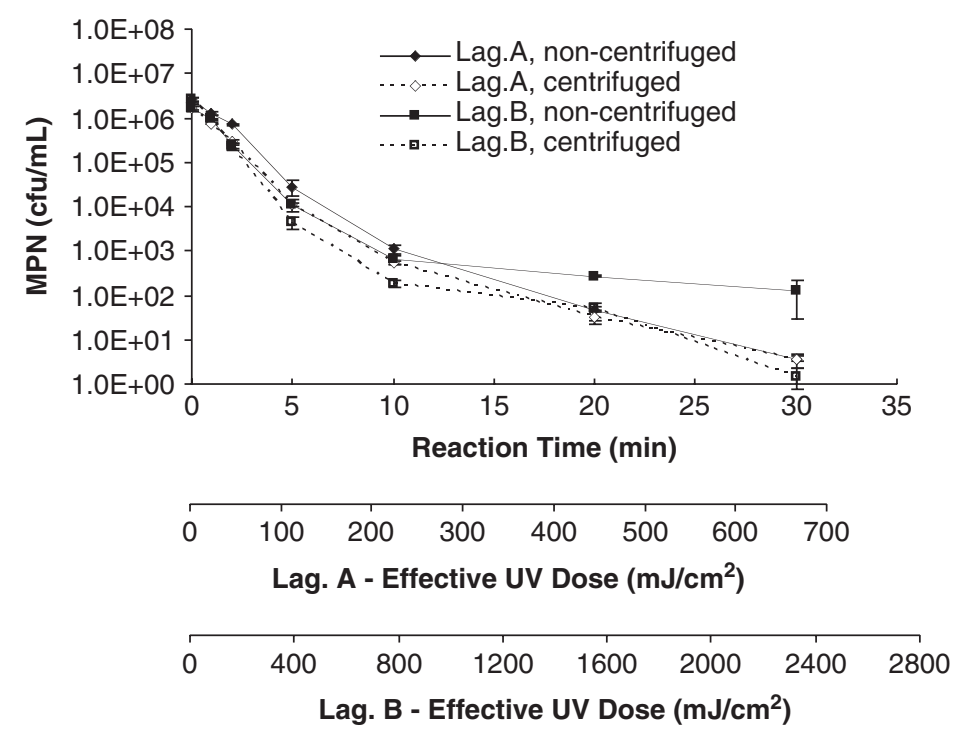

Fig. 4 - Effect of UV dose on bacteria inactivation. Data are from 3-tube MPN assays that were run twice (mean of $\mathrm{MPN} \pm$ standard deviation). Experimental conditions: $10 \mathrm{mM} \mathrm{KH}_{2} \mathrm{PO}_{4}, \mathrm{pH} 7.7$, room temperature $\left(23 \pm 1^{\circ} \mathrm{C}\right)$.

of $10 \mathrm{~min}$, which corresponds to an effective UV dose of $220 \mathrm{~mJ} / \mathrm{cm}^{2}$ for lagoon A samples and $770 \mathrm{~mJ} / \mathrm{cm}^{2}$ for lagoon $B$ samples, a bacteria inactivation efficiency of 3.4-4.2 log could be achieved that reduced the number of bacteria to less than $1000 \mathrm{cfu} / \mathrm{mL}$ in all samples. Further increasing the irradiation time to $30 \mathrm{~min}$, which corresponds to an effective UV dose of $660 \mathrm{~mJ} / \mathrm{cm}^{2}$ for lagoon A samples and $2300 \mathrm{~mJ} / \mathrm{cm}^{2}$ for lagoon B samples, could essentially inactivate all bacteria in lagoon samples (except the non-centrifuged Lagoon B sample that had only about $100 \mathrm{cfu} / \mathrm{mL}$ bacteria left). It is seen that the UV irradiation is unlikely to be economically feasible due to its high energy consumption. The commonly applied UV dose for disinfecting wastewater is generally less than $100 \mathrm{~mJ} / \mathrm{cm}^{2}$ (Bourrouet et al., 2001; Jolis et al., 2001). Occasionally, a UV dose of $170-300 \mathrm{~mJ} / \mathrm{cm}^{2}$ has been applied to achieve a higher efficiency of bacteria inactivation (Thompson et al., 2003; Lazarova and Savoys, 2004).

\subsection{Disinfection with ozone}

The effect of ozone dose on bacteria inactivation in centrifuged lagoon samples is shown in Fig. 5. It was observed that there exists an initial lag phase on the disinfection curves. The bacteria inactivation was ineffective up to an ozone dose of 20 and $10 \mathrm{mg} / \mathrm{L}$ for Lagoon A and Lagoon B samples, respectively. It implies that at a low ozone dose, the majority of ozone was preferentially consumed by natural organic materials (non-bacterial) present in lagoon samples. Since Lagoon A contained more natural organic materials than Lagoon B, as reflected by the values of COD and DOC 


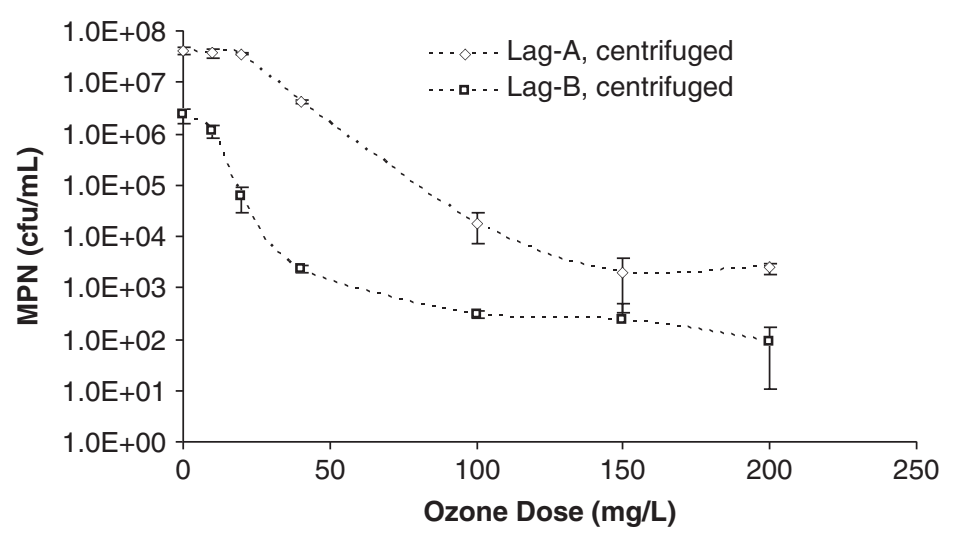

Fig. 5 - Effect of ozone dose on bacteria inactivation. Data are from 3-tube MPN assays that were run twice (mean of $\mathrm{MPN} \pm$ standard deviation). Experimental conditions: $10 \mathrm{mM} \mathrm{KH}_{2} \mathrm{PO}_{4}, \mathrm{pH} 7.7,2.5 \mathrm{~h}$ disinfection time (on ice).

listed in Table 1, more ozone was required to pass this lag phase for the Lagoon A sample. After the lag phase, bacteria could be effectively inactivated. At the ozone dose of $100 \mathrm{mg} /$ $\mathrm{L}$, the efficiency of bacteria inactivation could reach 3.3 and 3.9log for Lagoon A and Lagoon B samples, respectively. Further increasing the ozone dose did not significantly enhance the bacteria removal efficiency, probably due to accelerated self-decomposition of ozone at a high concentration.

\section{Discussion}

As described above, chlorine is relatively effective in inactivating lagoon bacteria. At a moderate dose of $30 \mathrm{mg} / \mathrm{L}$ chlorine, a bacteria inactivation efficiency of 2.2-3.4 log could be readily achieved. The real disinfectant, however, was monochloramine instead of free chlorine due to the presence of a large amount of dissolved ammonia. If ammonia is removed from the lagoon wastewater prior to chlorination, the disinfection efficiency may be greatly improved because free chlorine has a much stronger disinfection potential than monochloramine. One potential mechanism of ammonia removal is the precipitation of struvite (magnesium ammonium phosphate, $\mathrm{MgNH}_{4} \mathrm{PO}_{4} \cdot 6 \mathrm{H}_{2} \mathrm{O}$ ), a promising technology for both $\mathrm{N}$ and $\mathrm{P}$ removal from anaerobic swine lagoon effluent (Nelson et al., 2003). In addition, the retention time of the swine wastewater is as long as several months due to the small flow rate of the wastes into the anaerobic lagoons, as informed by the CAFOs operators. Therefore, an extended reaction time may be applied to improve the disinfection efficiency.

In this study, the chlorination experiments were conducted at $\mathrm{pH} 7.7$ where free chlorine consisted of approximately $50 \%$ hypochlorous acid ( $\mathrm{HOCl}$ ) and 50\% hypochlorite $\left(\mathrm{OCl}^{-}\right)$ $\left(p K_{a}=7.63\right.$ at $15^{\circ} \mathrm{C}$, Morris, 1966). The $\mathrm{pH}$ value of the lagoon sample, which controls the speciation of $\mathrm{HOCl}$, is critical to disinfection effectiveness because the relative disinfection efficiency of $\mathrm{HOCl}$ is about 40-80 times that of $\mathrm{OCl}^{-}$ (Tchobanoglous and Burton, 1991). It is thus reasonably expected that after ammonia removal, lowering the sample $\mathrm{pH}$ (i.e., increasing the fraction of $\mathrm{HOCl}$ ) will significantly enhance the disinfection efficiency. However, without ammonia removal, changing $\mathrm{pH}$ does not seem to affect the disinfection activity notably because the primary disinfectant is monochloramine. The $p \mathrm{~K}_{\mathrm{a}}$ value of monochloramine was reported to be about -1.45 (Gray et al., 1978), so the speciation of monochloramine is negligible except under an extremely acidic $\mathrm{pH}$ condition.

UV light has become widely accepted for wastewater disinfection. There are now over 2000 wastewater treatment plants using either low- or medium-pressure UV technology worldwide (Kalisvaart, 2004). UV irradiation could effectively inactivate bacteria in lagoon samples. However, this technology is limited by its high energy consumption due to the strong absorbance of UV light by lagoon wastewater. The UV transmittances at $254 \mathrm{~nm}$ are only $0.10 \%$ and $2.19 \%$ at $1-\mathrm{cm}$ light path length for the centrifuged Lagoon A and Lagoon B samples, respectively (Table 1). The suspended solids in lagoon samples also inhibit the penetration of UV to bacteria. Therefore, the UV irradiation technology seems inapplicable to swine lagoon bacteria.

The disinfection curves of ozonation showed a similar shape to those of chlorination that leveled off above a certain chemical dose. As mentioned above, this is most probably due to the accelerated self-decomposition of ozone at a high concentration. It was reported that a transferred ozone dose of $30-50 \mathrm{mg} / \mathrm{L}$ achieved a $2 \log$ reduction of fecal coliform in the effluent of a wastewater treatment plant (Gehr et al., 2003). Our results show that an ozone dose of $100 \mathrm{mg} / \mathrm{L}$ could achieve a 3.3-3.9log reduction of total bacteria in lagoon samples, but about $1.1-1.8 \times 10^{4} \mathrm{cfu} / \mathrm{mL}$ bacteria still survived the ozone treatment. To suppress the self-decomposition of ozone at a high concentration, pulse dosing of ozone at a reduced concentration (e.g., $30-50 \mathrm{mg} / \mathrm{L}$ ) may be considered. Furthermore, due to the small flow rate of the swine lagoons, a total ozone dose as high as $200-300 \mathrm{mg} / \mathrm{L}$ may still be economically affordable.

\section{Conclusions}

This study investigated the disinfection potential of chlorine, ultraviolet light and ozone against swine lagoon bacteria to 
prevent the release of antibiotic-resistant bacteria into other environments. It was observed that a significant fraction of lagoon bacteria are resistant to the antibiotics investigated: CTC, LIN, SMN and TET. Chlorine could achieve a 2.2-3.4 log bacteria reduction at a dose of $30 \mathrm{mg} / \mathrm{L}$. However, two chlorine-resistant bacteria were isolated and identified as Bacillus subtilis and Bacillus licheniformis with $99 \%$ similarity to known species. UV irradiation was able to essentially inactivate almost all bacteria, but high energy consumption makes this technology infeasible due to the low UV transmittance in swine wastewater. Ozone could achieve a 3.3-3.9log bacteria reduction at a dose of $100 \mathrm{mg} / \mathrm{L}$.

\section{Acknowledgments}

This work was funded by the U.S. Environmental Protection Agency (Grant No. XP-99795901-0). Additional instrumental support was provided by the Environmental Research Center for Emerging Contaminants (UMR). The authors also thank Dr. Keith Loftin for analysis of antibiotics in lagoon wastewater and helpful discussions as well as Mei-Foong Mong and Alexis Takir who served as undergraduate research assistants on this project. We also acknowledge the constructive criticisms by two anonymous reviewers who greatly helped us to improve this manuscript.

\section{R E F E R E N C E S}

Atlas, R.M., Brown, A.E., Dobra, K.W., Miller, L., 1984. Experimental Microbiology_Fundamentals and Applications. Macmillan Publishing Company, New York (pp. 110-111).

Barker, J.C., Drigger, L.B., 1985. Pit recharge system for managing swine under floor manure pits. In: Agriculture Waste Utilization and Management; Proceedings of the Fifth International Symposium on Agriculture Wastes. ASAE, St. Joseph, MI, pp. 575-581.

Berman, D., Rice, E.W., Hoff, J.C., 1988. Inactivation of particleassociated coliforms by chlorine and monochloramine. Appl. Environ. Microbiol. 54 (2), 507-512.

Bourrouet, A., Garcia, J., Mujeriego, R., Penuelas, G., 2001. Faecal bacteria and bacteriophage inactivation in a full-scale UV disinfection system used for wastewater reclamation. Water Sci. Technol. 43 (10), 187-194.

Carlson, M.S., Fangman, T.J., 2000. Swine Antibiotics and Feed Additives: Food Safety Considerations. Agricultural Publication G2353, MU Extension, University of Missouri, Columbia.

Chee-Sanford, J.C., Aminov, R.I., Krapac, I.J., Garrigues-Jeanjean, N., Mackie, R.I., 2001. Occurrence and diversity of tetracycline resistance genes in lagoon and groundwater underlying two swine production facilities. Appl. Environ. Microbiol. 67 (4), 1494-1502.

Daughton, C.G., Ternes, T.A., 1999. Pharmaceutical and personal care products in the environment: agents of subtle change? Environ. Health Perspectives 107 (Suppl. 6), 907-938.

Dell, H., 2003. Antibiotics in the environment: not harmful after all? http://news.bmn.com (accessed July 4, 2003), 10:12 GMT.

Do, Y.S., Schmidt, T.M., Zhan, J.A., Boyd, E.S., de la Mora, A., DiSpirito, A.A., 2003. Role of Rhodobacter sp. strain PS9, a purple non-sulfur photosynthetic bacterium isolated from anaerobic swine waste lagoon, in odor remediation. Appl. Environ. Microbiol. 69 (3), 1710-1720.
Gehr, R., Wagner, M., Veerasubramanian, P., Payment, P., 2003 Disinfection efficiency of peracetic acid, UV and ozone after enhanced primary treatment of municipal wastewater. Water Res. 37 (19), 4573-4586.

Goni-Urriza, M., Capdepuy, M., Arpin, C., Raymond, N., Caumette, P., Quentin, C., 2000. Impact of an urban effluent on antibiotic resistance of riverine Enterobacteriaceae and Aeromonas spp. Appl. Environ. Microbiol. 66 (1), 125-132.

Gray Jr., E.T., Margerum, D.W., Huffman, R.P., 1978. Chloramine equilibriums and the kinetics of disproportionation in aqueous solution. In: Brinckman, F.E., Bellama, J.M. (Eds.), Organometals and Organometalloids: Occurrence and Fate in the Environment. ACS Symposium Series 82. American Chemical Society, Washington, DC, pp. 264-277.

Hansen, K.H., Angelidaki, I., Ahring, B.K., 1998. Anaerobic digestion of swine manure: inhibition by ammonia. Water Res. 32 (1), 5-12.

Hilpert, R., Winter, J., Kandler, O., 1984. Agricultural feed additives and disinfectants as inhibitory factors in anaerobic digestion. Agric. Wastes 10 (2), 103-116.

Jolis, D., Lam, C., Pitt, P., 2001. Particle effects on ultraviolet disinfection of coliform bacteria in recycled water. Water Environ. Res. 73 (2), 233-236.

Kalisvaart, B.F., 2004. Re-use of wastewater: preventing the recovery of pathogens by using medium-pressure UV lamp technology. Water Sci. Technol. 50 (6), 337-344.

Kobayashi, H.A., Stenstrom, M., Mah, R.A., 1983. Use of photosynthetic bacteria for hydrogen sulfide removal from anaerobic waste treatment effluent. Water Res. 17 (5), 579-587.

Kolpin, D.W., Furlong, E.T., Meyer, M.T., Thurman, E.M., Zaugg, S.D., Barber, L.B., Buxton, H.T., 2002. Pharmaceuticals, hormones, and other organic wastewater contaminants in U.S. streams, 1999-2000: a national reconnaissance. Environ. Sci. Technol. 36, 1202-1211.

Krapac, I.G., Dey, W.S., Smyth, C.A., Roy, W.R., 1998. Impacts of bacteria, metals, and nutrients on groundwater at two hog confinement facilities. In: Proceedings of the National Ground Water Association Animal Feeding Operations and Groundwater: Issues, Impacts, and Solutions-A Conference for the Future. National Groundwater Association, St. Louis, MO, pp. 29-50.

Krapac, I.G., Dey, W.S., Roy, W.R., Jellerichs, B.G., Smyth, C., 2000. Groundwater quality near livestock manure pits. In: Proceedings of the Eighth International Symposium on Animal, Agricultural and Food Processing Wastes. American Society for Agricultural Engineering, Des Moines, Iowa, pp. 710-718.

Lazarova, V., Savoys, P., 2004. Technical and sanitary aspects of wastewater disinfection by UV irradiation for landscape irrigation. Water Sci. Technol. 50 (2), 203-209.

Miner, J.R., Humenik, F.J., Overcash, M.R., 2000. Managing Livestock Wastes to Preserve Environmental Quality. Iowa State University Press, Ames, IA.

Morris, J.C., 1966. The acid ionization constant of $\mathrm{HOCl}$ from 5 to $35^{\circ}$. J. Phys. Chem. 70, 3798-3805.

Nelson, N.O., Mikkelsen, R.L., Hesterberg, D.L., 2003. Struvite precipitation in anaerobic swine lagoon liquid: effect of $\mathrm{pH}$ and $\mathrm{Mg}: \mathrm{P}$ ratio and determination of rate constant. Bioresour. Technol. 89 (3), 229-236.

Poels, J., Van Assche, P., Verstraete, W., 1984. Effects of disinfectants and antibiotics on the anaerobic digestion of piggery waste. Agric. Wastes 9 (4), 239-247.

Qiang, Z., Adams, C., 2004. Determination of monochloramine formation rate constants with stopped-flow spectrophotometry. Environ. Sci. Technol. 38 (5), 1435-1444.

Salmon, S.A., Watts, J.L., Case, C.A., Hoffman, L.J., Wegener, H.C., Yancey Jr., R.J., 1995. Comparison of MICs of ceftiofur and 
other antimicrobial agents against bacterial pathogens of swine from the United States, Canada, and Denmark. J. Clin. Microbiol. 33 (9), 2435-2444.

Sweeten, J.M., 1980. Waste treatment: state-of-the-art. In: Livestock Waste: A Renewable Resource; Proceedings of the Fourth International Symposium on Livestock Wastes. ASAE, St. Joseph, MI, pp. 334-338.

Tchobanoglous, G., Burton, F.L., 1991. Wastewater Engineering: Treatment, Disposal, and Reuse, third ed. (Metcalf \& Eddy, Inc.), McGraw-Hill, Inc., New York (p. 333).

Thompson, S.S., Jackson, J.L., Suva-Castillo, M., Yanko, W.A., El Jack, Z., Kuo, J., Chen, C.L., Williams, F.P., Schnurr, D.P., 2003. Detection of infectious human adenoviruses in tertiarytreated and ultraviolet-disinfected wastewater. Water Environ. Res. 75 (2), 163-170.

Tolls, J., 2001. Sorption of veterinary pharmaceuticals in soils: a review. Environ. Sci. Technol. 35, 3397-3406.
USDA, Natural Resources Conservation Service, 1999. Agriculture Waste Management Field Handbook. NEH-651, Washington, DC (pp. 4-12)

US EPA, 2003. NPDES Permit Writers' Guidance Manual and Example NPDES Permit for Concentrated Animal Feeding Operations. EPA-833-B-04-001, Washington, DC.

Venkobachar, C., Iyengar, L., Rao, A.V.S.P., 1997. Mechanism of disinfection: effect of chlorine on cell membrane functions. Water Res. 11, 727-729.

Walsh, C., 2003. Antibiotics: Actions, Origins, Resistance. ASM Press, Washington, DC (p. 335).

White, G.C., 1992. The Handbook of Chlorination and Alternative Disinfectants, third ed. Van Nostrand Reinhold, New York (pp. 1217-1218).

Zahn, J.A., Hatfield, J.L., Laird, D.A., Hart, T.T., Do, Y.S., DiSpirito, A.A., 2001. Functional classification of swine manure management systems based on effluent and gas emission characteristics. J. Environ. Qual. 30, 635-647. 